\title{
CONTRIBUTIONS TO THE ORNITHOLOGY OF SOUTH CHINA. PART II.
}

\author{
By
}

The Marquess Hachisuka, Ph. D.

THE BIRD SPECIMENS EXAMINED AT NANNING.

On Saturday, May 25, 1940, after a little less than two hours flight from Canton a heavy bomber of the army landed me safely at the aerodrome of Nanning, the capital of Kwangsi Province. The town was at that time still deserted by the Chinese and not a single citizen could be seen in the streets. The inhabitants one meets are those wearing khaki uniforms; not a single woman, child, or dog was visible. It was a pitiful sight to see empty bird cages still hanging at the windows of entirely vacant houses with their doors flung open. Some potted flowers were dried up on a dusty table.

The Japanese Army have been preserving all the public properties, and amongst them are collections of birds. This institution is called Kwangsi Provincial Museum of Natural History and its collections are orderly exhihibited in glass cases. The bird specimens, which occupy the largest proportion of the floor space, are shown together with mammals, fishes, and timber. As Kwangsi is one of the least explored provinces in China, the collection proved to be of great scientific value. I at once spotted several birds hitherto only known from Burma and Yunnan, or supposed to have been confined to the mountains of Hainan. As a portion of the Oriental Region, southeastern China is poor in birds, this Nanning collection proved to be of great interest as it contained several birds recently discovered and newly recorded for the whole of China. Two of these, on my careful examition proued to the new subspecies and consequently, I described them in Washington). ${ }^{1)}$ The list on the follow-

1) Proc. Biol. Soc. Wash., vol. 54, pp. 49-50, May 20, 1941. 
ing pages, although not large, is therefore of importance.

For the sake of convenience, I have added to those birds less known among Chinese and Japanese literature, their foreign distribution and allied species and subspecies.

Due to shortness of time it is regretted that all the specimens examined are not listed in every cass; consequently, the number of commoner and migratory species have been omitted.

With the aid of two soldiers who assisted me, I was able to complete my cataloguing in a room heavily infested with mosquitos.

The Japanese force entering Tonkin resulted in Nanning loosing its' strategic importancy; and was evacuated in the autumn, about three months after my visit.

This is to wish that the Natural History Museum of Nanning may flourish under the new management, and that the present article forms a welcome contribution which may serve to widen the ornithological knowledge of Kwangsi, one of the least known, yet ornithologically richest Chinese provinces. 


\section{PICA PICA SERICEA Gould}

Chinese Magpie

La Touche, "Handb. Bds. E. China," I, p. 13, 1925.

\section{PARUS MAJOR ARTATUS Thayer \& Bangs North China Tit}

La Touche, "Handb. Bds. E. China," I, p. 23, 1925.

Four specimens.

\section{MACHLOLOPHUS REX (A. David) \\ David's Yellow-chceked Tit}

La Touche, "Handb. Eds. E. China," I, p. 30, 1925.

Four specimens.

The present genus has the following three species and subspecies, but Delacour considers all the three species as races of xanthogenys, cf. L'Oiseau, p. 200, 1940.

Allied Species and their Ranges:

$M$. spilonotus spilonotus (Blyth).

Nepal to Miri Hills north of the Bramaputra hills, south of Brahmaputra to Looshai and Lakhimpur and probably Chin Hills. M. s. subviridis (Tickell).

Burma, Siam, Shan States and south to Mt. Muleyit in Tenasserim.

M. $s$, basileus Delacour.

Lower Laos (Bolovens) and South Annam (Langbian).

$M$. xanthogenys xanthogenys (Vigors).

Murree to Nepal and Sikkim.

M. x. aplonotus (Blyth).

Throughout the peninsula of India south of line drawn from Abu to Paresnath in Chota Nagpur up to 6,000 ft.

$M$. rex (A. David).

Mountains of north and central Fukien, southeast Yunnan, 
Kwangsi, northeast Tonkin and high Laos (Tranninh).

\section{EGITHALISCUS CONCINNUS CONCINNUS (Gould)}

$$
\text { Red-headed Tit ジアカェナガ }
$$

La Touche, "Handb. Bds. E. China," I, p. 33, 1925.

One specimen.

Allied. Forms and their Range:

AE. concinnus iredalei S. Baker.

Himalayas from Chitral to the Mishimi Hills over 5,000 feet and over 4,000 in the Miri Hills, eastwards to Sikkim.

AE. c. rubricapillus Ticehurst.

Sikkim.

AE. c. manipurensis Hume.

Hill ranges south of the Brahmaputra, Manipur, Laoshai and extremely northern ranges of the Chin Hills.

A. c. pulchellus Rippon.

South Shan States, Karenni.

A. c. talifuensis Rippon.

Mt. Talifu, W. Yunnan, S.W. China and N. Shan States as far west as the Irrawaddy.

A. c. tonkinensis Delacour et Jabouille.

Northeast Tonkin and Tranninh in High Laos.

E. c. concinnus (Gould).

Yangtse Valley to Szechwan, Chekiang, Fukien, Kwangtung, and once in Shaweishan. Formosa.

\section{SUTHORA WEBBIANA FULVICAUDA Camplell \\ Fukien Crow-Tit ダルマエナガ}

La Touche, "Handb. Bds. E. China," I, p. 50, 1925.

Specimens examined in Nanning Museum came from Hochï

(河池).

Allied Forms and their Range: 


\section{DRYONASTES SANNIO (Swinhoe) \\ White-cheeked Laughing Thrusb}

La Touche, "Handb. Bds. E. China," p. 55, 1925.

Five specimens.

Distribution.-Very rare in Chacar Hills and Manipur, and it became extremely common in Chin and Kachin Hills where it is found between 3,000 and 5,000 feet; and all the hills of IndoChina as far south as Laos and northern Annam.

In China they are found in the hills south of the Yangtse, in Kiangsi, Hunan, Hupeh, Fukien, Kwangtung, Kwangsi, Yunnan, and Szechwan where northern birds undertake local migration during the winter month.

\section{DRYONASTES CHINENSIS CHINENSIS (Scopoli)}

Black-throated Laughing-Thrush

La Touche, "Handb. Bds. E. China," I, p. 57, 1925.

One specimen.

Allied Forms and their Range:

D. chinensis chinensis (Scopoli).

Syn, D. leucogenys Blyth-China.

Kwangtung, Hongkong and Kwangsi, Tonkin, Laos, north and central Annam.

D. c. lowi La Touche.

E. Yunnan.

D. c. form. dim. lugens (Oustalet).

Tonkin, high-Laos, north and central Annam.

D. c. propinquus Salvadori.

Southern Shan States, Toughoo to the southern half of Pegu and Yunnan (partial).

TROCHALOPTERON CANORUM CANORUM (Linnaeus)

Hwamei

La Touche, "Handb. Bds. E. China," vol. I, p. 63, 1925. 
S. webbiana webbiana Gray.

Shanghai country in Yangtse Delta.

S. w. rosea La Touche.

N. W. Chihli.

S. w. pekinensis La Touche.

Peking.

S. w. fulvicauda Campbell.

West and East Chihli and Korea. La Touche thinks East and West Chihli birds are separable ("Handb. Bds. E. China." vol. i, p. 50, 1925).

S. w. suffusa Swinhoe.

Yangtse Valley from Chinkinng, inclusive to Hupeh and northwards to the Tsingling and northern Tonkin (Pakha).

S. w. fohkienensis La Touche.

Western Fukien probably N. W. Kwangtung.

S. $w$. bulomachus Swinhoe.

Formosa.

S. w. intermedia (Delacour et Jabouille).

Northeast Tonkin (Fansipan).

S. w. brunnea Anderson.

Yunnan and the Kachin hills from Bhamo eastwards.

\section{DRYONASTES PERSPICILLATUS PERSPICIL-}

\section{LATUS (Gmelin)}

Black-faced Laughing-Thrush

La Touch, "Handb. Bds. E. China," I, p. 55, 1925.

Five specimens.

Allied Forms and their Range:

D. perspicillatus perspicillatus (Gmelin)

Yangtze Valley, Szechuen, Fohkien, Kwangtung, and Kwangsu.

Tonkin, Laos, north and central Annam.

D. p. shensiensis Riley.

Shensi.

Delacour does not seem to recognize the present race. 
Allied Forms and their Range:

T. canorum canorum (L.)

Kiangsi, Kiangsu, Anhwei, Chekiang, Fukien, Kwangtung, and now recorded for the first time from Kwangsi. Tonkin, High Laos and north Annam.

T. c. namtiense La Touche.

Yunnan-Tonking border.

T. c. owstoni Rothschild.

Hainan.

T. c. taevanum (Swinhoe).

Formosa.

\section{TROCHALOPTERON MILNI SINIANUM Stresemann}

Sin's Crimson-winged Laughing-Thrush

Stresemann, “Orn. Monatsb.," p. 47, March 3, 1930.

La Touche, "Bandb. Bds. E. China," I, p. 64, 1925.

Six specimens, all taken above $6,000 \mathrm{ft}$.

Allied Forms and their Range:

Trochalopteron m. milni A. David.

N. W. Fukien.

T. m. sinianum Stresemann.

T. m. indochinensis Delacour.

Tonkin, Kwangsi.

T. m. sharpei Rippon.

Kachin Hills, north Shan States. High Laos (Tranninh). The birds from northeast Tonkin is intermediated with the preceeding bird.

T. m. vitryi (Delacour):

Lower Laos (Bolovens).

BABAX LANCEOLATUS LATOUCHEI Stresemann

Babax

“Orn. Monatsb." 1929, XXXVII, p. 140. Yaoshan. 
La Touche, "Handb. Bds. E. China," I, p. 65, 1925.

Allied Forms and their Range:

Babax lanceolatus latouchei Stresemann.

South Shensi, Huphe, W. Szechwan, Kwangsi, W. Hunan, Yunnan, Fukien.

B. l. lanceolatus (Verreaux).

E. Tibet, Kachin Hills, N. Shan States.

B. l. woodi Finn.

Chin Hills.

\section{POMATORHINUS RUFICOLLIS STRIDULUS Swinhoe East China Lesser Scimitar-Babbler}

La Touche, "Handb. Bds. E. China," I, p. 66, 1925.

Three specimens.

Allied Forms and their Range:

$P$. ruficollis ruficollis Hodgeson.

Himalayas, Nepal to Eastern Assam, North of the Brahmaputra.

$P$. r. bakeri Harington.

Hills south of the Brahmaputra in Assam; Manipur, Lushai, Chin Hills, Kachin Hills.

P. r. eidoes Bangs (1930).

Szechwan.

P. r. albipectus La Touche.

North L Laos.

$P$. $r$. beaulieui Delacour et Greenway.

High Laos (Tranninh and Luang-Prabang).

$P$. r. saturatus Delacour.

Tonkin and North Annam.

$P$. $r$. stridulus Swinhoe.

Fukien, Kiangsi, Kwangtung, Kwangsi.

$P$. r. nigrostellatus Swinhoe.

Hainan.

$P$. $r$. musicus Swinhoe.

Formosa. 
Delacour (1940) in his Indo-Chinese list considers schisticeps, olivaceus, and ruficollis all conspecific.

\section{POMATORHINUS SWINHOEI ABREVIATUS Stresemann}

Yaoshan Large Scimitar-Babbler

Journ. für Orn., LXXVII, p. 333, 1929, Yaoshan.

La Touche, "Handb. Bds. E. China" I, p. 69, 1925.

One specimen.

This well defined species is a resident of South China and was found for the first time from Yaoshan by Prof. Yen.

Allied Forms and their Range:

P. s. odicus Bangs \& Phillips.

Yunnan.

P. s. swinhoei A. David.

Kwangtung, Kwangsi, Fukien, Anhwei, Chekiang and Kwangsi.

P. s. abreviatus Stresemann.

Yaoshan.

\section{POMATORHINUS ERYTHROGENYS subsp.? \\ Scimitar-Babbler}

Baker, "Faun. Brit. India," I, p. 221, 1922.

Delacour \& Jabouille, Ois. Indoch., vol. III, p. 260, 1937.

The present species of Scimitar-Babbler is recorded for the first time from China, however unfortunately I have left the specimen in Nanning Museum and am now unable to determine its subspecies. According to Baker, $P$. e. gravivox is found as far east as Bhamo Hills, Yunnan and Delacour and Jabouille assigned the name minor for the birds found in northwest Tonkin and High Laos while Rothschild assignes, in his Yunnanese paper, imberbis to the west Yunnanese bird.

Specimens in Nanning Museum came from Hsiang hsien (象縣)

Allied Forms and their Range:

$P$. erythrogenys erythrogenys Vigors. 
N. W. Himayas to Simla.

P. e. haringtoni S. Baker.

Himalayas, Garhwal to Sikkim.

$P$. e. macclellandi Jerdon.

Assam, south of the Brahmaputra and Chin Hills.

P. e. gravivox David.

Bahamo Hills, Yunnan.

P. e. imberbis Salvadori.

Hills of eastern Burma from the Ruby Mines to Tenasserim.

P. e. minor Delacour.

Northeast Tonkin and High Laos (Phongsaly and Tranninh).

\section{STACHYRIS STRIOLATA SINENSIS (Stresemann) \\ Chinese Spotted Babbler}

Thringorhina guttata sinensis Stresemann, "Orn. Monatsb.," 1929, XXXVII, p. 141. Yaoshan.

Two specimens.

The member of this ground inhabiting Timaline bird was collected for the second time from China.

Allied Forms and their Range:

S. striolata striolata (S. Müller).

Sumatra (west).

S. s. umbrosa (Kloss).

Sumatra (northeast).

S. s. guttata (Blyth).

Peninsular Siam, Burma, Siam. It has been obtained in the extremely south Tenasserim and in Kao Nawng and Trang in Siam.

S. s. tonkinensis Kinnear.

Bull. Brit. Orn. Club, CCCCXII, p. 82, April 1938, nom. nov., Tringorhina striolata diluta Kinnear, Bull. Brit. Orn. Club, XLV, p. 11, 1924. Thainien.

Tonkin, North Annam.

S. s. helence Delacour et Greenway. 
Bull. Brit. Orn. Club, LIX, p. 131, June 1939, Nam-Khueng. Upper Laos.

\section{STAPHIDIA STRIATA TORQUEOLA (Swinhoe) \\ Collared Staphidia}

La Touche, "Handb. Bds. E. China," I, p. 77, 1925.

Two specimens.

In his recent handlist of the Indo-Chinese bird, Delacour placed Staphidia under Siva and torqueloa as a race of striata but I follow Baker, Chasen and La Touche keeping the present genus as it is and two distinct geographical representatives as species.

The genus includes the following species and subspecies.

Allied Species and their Range:

S. castaneiceps castaneiceps (Moore).

Assam Hills, south of the Brahmaputra as far east as the Naga Hills and south to Lushai, also known from Dafla Hills.

S. c. everetti Shape.

Borneo.

S. striata striata (Blyth).

Tenasserim northwards through the hills of eastern Burma to Bhamo in the Chin Hills.

S. s. rufigenis (Hume).

Sikkim to Assam, north and east of the Brahmaputra, Abor and Miri Hills. Also recorded from Kachin Hills.

S. torqueola (Swinhoe).

Tonkin, High Laos, north and central Annam, Kwangsi, Kwangtung, and Fukien.

SIVA CYANOUROPTERA YAOSHANICA Hachisuka

Blue-wing Siva

Hachisuka, Proc. Biol. Soc. Wash., vol. 54, p. 50, May 20, 1941.

Two specimens.

Genus Siva is discovered for the first time from China. It includes two species and several respective races. 
Allied Species and their Range:

S. strigula strigula Hodgson.

The Himalayas from the Sutlej Valley to Eastern Assam, north and south of Brahamputra Valley.

S. s. castaneicauda Hume.

Burma from Tenasserim to the Chin and Kachin Hills and Siam.

S. s. malayana Hartert.

Malay States.

S. s. yunnanensis Rothschild.

Yunnan, N.E. Tonkin, and Laos.

S. cynanouroptera cynaouroptera Hodgson.

Himalayas from Naini-Tal to E. Assam, North and South of the Brahmaputra, Manipur, Lushai, Chittagong Hill tracts and Chin Hills.

S. c. wingatei $\mathrm{O}$. Grant.

Kachin Hills to Yunnan, Shan States, N.E. Tonkin, Upper Laos and North Tonkin.

S. c. sordida Hume.

Mt. Muleyit, Tenasserim.

S. c. oatesi Harington.

Mt. Byingyi, border of Shan States.

S. c. orientalis Robinson \& Kloss.

South Annam, Lower Laos.

S. c. sordidior Sharpe.

Malay Peninsula.

Delacour (1931 and 1940) unites Staphidia to Siva but I follow Baker (1922) and Chasen (1935) and keep the two genera as distinct.

YUHINA NIGRIMENTUM PALLIDA La Touche Chinese Black-chinned Yuhina

La Touche, "Handb. Bds. E. China," I, p. 78, 1925.

Four specimens.

Allied Forms and their Range: 
Y. nigrimentum xigvimentum Hoügzon.

The Himalayas from Garhwal to Assam, north and south of the Brahmaputra, Manipur, Chin Hills and north Arrakan.

Y. n. pallida La Touche.

Syn. Y. n. intermedia Rothschild. Yunnan.

High Laos, Tonk:- north Annam, Yunnan, Kwangsi, and northwest Fukien.

\section{ERPORNIS XANTHOLEUCA GRISEILORIS (Stresemann)}

Chinese Herpornis

La Touche, "Handb. Bds. E. China," I, p. 79, $192 .$.

A specimen at Nanning Muscum came from Hsiang hsicn (象縣). Allied Forms and their Range.

E. $x$. xantholeuca Hodgeson.

Himalayas from Nepal to Assam, north and south of the Brahmaputra, Manipur, Burma; Siam and north Malay Peninsula.

E. x. interposita (Hartert).

Malay Peninsula.

E. $x$. brunnescens Sharpe.

Borneo.

E. $x$ griseiloris (Stresemann).

Tonkin, Annam, Laos; Yunnan, Kwangsi, Kwangtung, Fukien, and Formosa.

$E$. $x$. sordida Robinson \& Kloss.

Cochin-China, centre and south Annam, lower Laos (Bolovens).

E. $x$. canescens Delacour et Jabouille.

Cambodia (Chaine de l'Elephant).

E. $x$. tyrranulus (Swinhoe).

Hainan.

\section{MICROSCELIS LEUCOCEPHALUS LEUCOCEP- HALUS (Gmelin) \\ White-headed Black Bulbul}

La Touche, "Handb. Bds. E. China," I, p. 87, 1925. 
One of the two specimens examined at Nanning Museum has the head flecked with white while the other is entirely white.

Much have been written on leucocephalus of the western Chinese and Indo-Chinese specimens yet nothing seems to have been definitely settled.

In this review the continental birds are considered as one and its respective races in Formosa and Hainan have their heads always totally black.

Allied Species and their Range:

The genus includes three species, one is a Japanese bird amaurotis, and the other two are psaroides and leucocephalus. The latter two, mostly in black, are reviewed below.

M. leucocephalus leucocephalus (Gmelin).

South Anhwei, Chekiang, Fukdien, Kwangtung, Kwangsi, Szechuen, Hupeh, Yunnan, Tonkin, Laos and Annam.

M. l. perniger (Swinhoe).

Hainan.

M. l. nigerrimus (Gould).

Formosa.

M. psaroides psaroides (Vigor).

Western Himayas to Bhutan.

M. p. nigrescens S. Baker.

South Assam, Manipur, Arrakan, northern Chin Hills, east to Chindwin but not to the Irrawaddy. Northeast Assam and Abor Hills.

M. p. concolor (Blyth).

Eastern Burma, Shan States, Yunnan, Siam and South Burma to Muleyit Mountain.

M. p. ganeesa (Sykes).

India, south from Matheran and Ceylon.

\section{IXOS CASTANONOTUS CANIPENNIS (Seebohm)}

Fohkien Chestnut Bulbul

La Touche, "Handb. Bds. E. China," I, p. 90, 1925. 
Four specimens.

La Touche ("Handb. Bds. E. China," vol. i, p. 90, 1925) considered canipennis as a race of castanonotus. Delacour (1931 also the latest liste 1940) considered the two to be distinct species on the ground that he (Ois. Indoch. iv, p. 26, 1931) found both together at Tamdao in northern Tonkin. It is however, this overlapping range is quite small and their breeding habit is still unknown, therefore I have kept them to be conspecific.

Delacour considers Tamdao specimens to be different from the Hainan birds. (P. 25, 1931).

Allied Forms and their Range:

I. castanonotus castanonotus (Swinhoe).

Northeast Tonkin (Tamdao), and Hainan.

I. c. canipennis (Soebohm).

Northeast Tonkin (Backan, Tamdao), Fukien, and Kwangtung.

PYCNONOTUS SINENSIS STRESEMANNI La Touche Lesser Chinese Bulbul

La Touche, "Handb. Bds. E. China," I, p. 94, 1925.

Allied Forms and their Range:

$P$. sinensis sinensis (Gmelin).

Sino-Tonkinese frontier (Langson), Kwangtung to Shanghai, Yangtse Valley including Szechwan.

P. s. stresemanni La Touche.

N. W. Fukien, probably mountains parts of western Fukien and of Kwangtung and Yaoshan. This is a small mountain breeder and its exact distribution is not yet known.

$P$. s. brevirostris Hachisuka.

Hainan.

P. s. formose Hartert.

Formosa (north and west).

P. s. orii Kuroda.

South Riu Kiu Islands (Yonakuni, ? Ishigaki). 


\section{PYCNONOTUS AURIGASTER ANDERSONï (Swinhoe)}

\section{Swinhoe's Yellow-vented Bulbul}

La Touche, "Handb. Bds. F. China," I, p. 94, 1925.

Having brought home no specimens from Nanning I cannot say for certain whether the Yaoshan bird should belong to the present race or P.a. xanthorrhous of Yunnan, a darker bird with a much deeper brown breast band. Yen assignes andersoni to his specimen.

Allied Forms and their Range:

$P$. aurigaster andersoni (Swinhoe).

Shensi, Yangtse Vallcy (Szechwan to Kiangsu), Kiangsi, Fukien, and N. W. Kwangtung.

$P$. a. xanthorrhous Anderson.

Eastern Burma from Karenni to Kachin Hills (Kakhyen),

Shan States, Yunnan, Kwangsi, N. E. Tonkin and High Laos.

P. a. thais Kloss.

Southeast Siam.

$P$. a. aurigaster (Vieillot).

Singapore Island (introduced), Sumatra (introduced), Banka and Java.

\section{OTOCOMPSA JOCOSA JOCOSA (Linnaeus) \\ Chinese Red-whiskered Bulbul}

La Touche, "Handb. Bds. E. China," I, p. 95, 1925.

Allied Forms and their Range:

Otocompsa jocosa is very closely related to O. emeria of India and some authors consider them as conspecific.

O. j. jocosa, (Linnaeus).

Kwangtung, Kwangsi, Tonkin, High Laos, and north Annam.

O. j. erythrotis (Bonaparte)

Cochin-China, South Annam, Lower Laos, Malay Peninsula, Sumatra (? introduced) and Java (? introduced).

o. $j$. hainanensis Hachisuka.

Hainan. 
O. j. pequensis S. Baker.

South Chin Hills, south Kachin Hills to Tenasserim, Arrakan, central hills of Burma, Siam and Shan States, Andamans and Nicobars.

o. j. fuscicaudata Gould.

South India, western Ghats to Rajuputana; Central Provinces and Behar in Central India.

\section{TURDUS MERULA MANDARINUS (Bonaparte) \\ Chinese Blackbird}

La Touche, "Handb. Bds. E. China," I, p. 100, 1925.

\section{TURDUS HORTULORUM Sclater}

Grey-backed Thrush

La Touche, "Handb. Bds. E. China," I, p. 104, 1925.

\section{OREOCINCLA AUREA AUREA (Hollandre) \\ White's 'Thrush}

La Touche, "Handb. Bds. E. China," I, p. 113, 1925.

\section{MONTICOLLA PHILIPPENSIS PANDOO (Sykes) \\ Eastern Blue Rock-Thrush}

La Touche, "Handb. Bds. E. China," I, p. 118, 1925.

\section{MYOPHONEUS CERULEUS CERULEUS (Scopoli) \\ Violet Whistling Thrush}

La Touche, "Handb. Bds. E. China," I, p. 126, 1925.

One specimen.

Specific validity of the members included in the present genus is not yet settled. Chasen recognizes six species from the Malaysian territory which may be united into three or four species by other 
authors. In the continental birds eugenii and temminckii must be considered conspecific. This idea is accepted by S. Baker in his last volume of "Fauna of British India, Birds," Delacour always maintains coeruleus and temminckii as being different species.

Allied Forms and their Range:

In the present review I have considered the continental birds as one species.

M. coeruleus coeruleus (Scopoli).

Entire East China from Chihli to Kwangtung, Kwangsi, Yunnan, Tonkin, north Annam, central and south Laos, and Cambodia (Bokor).

M. c. immansuetus Bangs \& Penard.

Hupeh and Szechuan.

M. c. eugenei Hume.

Eastern Burma, East of the Irrawaddy, Karenni, Pegu, Tenasserim, Siam, Shan States, Tonkin, Annam, Laos, and Cambodia. M. c. temminckii Vigors.

Himalayas from the Afghan frontier to the east of Assam, north and south of the Brahmaputra, Chin Hills, Arakan and the Kachin Hills between the Chindwin and the Irrawaddy.

\section{ENICURUS SCHISTACEUS (Hodgson) \\ Chinese Slaty-backed Forktail}

La Touche, "Handb. Bds. E. China," I, p. 135, 1925.

Distributions.-La Touche in 1925 applies leucoschistus of Seebohm to the Chinese birds, recognizing a Yunnanese bird as different; however, all the authors since that time consider schistaceus without races.

Kumaon to Eastern Assam, both north and south of the Brahmaputra, Burma, Siam, Shan States, Tonkin, Annam, Laos, Yunnan, Kwangsi, Kwangtung, and Fukien.

\section{RHYACORNIS FULIGINOSA FULIGINOSA (Vigors)}

Plumbeous Water-Redstart

La Touche, "Handb. Bds. E. China," II, p. 143, 1925. 
The present genus includes but one species and is closely related to Genus Chaimarrhornis.

Allied Forms and its Range:

R. fuliginosa fuliginosa (Vigors).

Himalayas from Afganistan and Baluchistan to Eastern Assam and Tibet; Northern Burma and the Burmese Hills to Tenasserim, Northern Siam, upper Tonkin, upper Laos and throughout China from N. Chihli to South Yunnan and Hainan.

R. f. affinis. (O. Grant).

Formosa.

\section{IANTHIA CYANURA CYANURA (Pallas) \\ Siberian Blue-Tail}

La Touche, "Handb. Bds. E. China," I, p. 148, 1925.

\section{COPSYCHUS SAULARIS PROSTHOPELLUS Oberholser Chinese Dayal Bird}

La Touche, "Handb. Bds. E. China," I, p. 149, 1925.

\section{SAXICOLA TORQUATA STEJNEGERI (Parrot)}

La Touche, "Handb. Bds. E. China," I, p. 153, 1925.

\section{RHODOPHILA FERREA HARINGTONI (Hartert) Chinese Gray Bush-Chat}

La Touche, "Handbk Bds. E. China," I, p. 154, 1925.

Two specimens, a male and female.

Delacour (1940) believes that haringtoni is not separable; however, I have followed the majority of author's view.

Allied Forms and their Range:

R. ferrea ferrea (Gray).

The western Himalayas from Chitral and the Eastern Assam, 
North and south of the Brahmaputra.

R. f. haringtoni (Hartert).

Hupeh, Fukien, Kwangtung, Kwangsi, Yunnan, Szechwan, Kachin and Chin Hills.

\section{ALSEONAX LATIROSTRIS POONENSIS (Sykes)}

Chinese Broad-billad Flycatcher

La Touche, "Handb. Brs. E. China," I, p. 156, 1925.

\section{CULICICAPA CEYLONENSIS ORIENTALIS Baker}

Chinese Grey-headed Flycatcher

La Touche, "Handb. Bds. E. China," I, p. 175, 1925.

The specimens examined at Nanning Museum came from $T$ 'ien pao (天保).

Allied Species and their Range:

The genus includes but two geographical species. C. ceylonensis is found throughout from India, Ceylon to South China and south to the Malayan countries as far southi as Flores and Sumba.

Many names have been proposed as races of ceylonensis but I have only recognized two in my book "The Birds of the Philippine Islands" vol. ii, p. 336, 1935; and orientalis of Baker from Szechwan and meridiondlis of Baker from Siam become synonyms of the typical race.

Kuroda's work in his "Birds of Java" 1933 recognized seven or eight names with full bibliography relating to this species.

It is not necessary to repeat all the former work and students are asked to look into the above two books.

\section{RHIPIDURA ALBICOLLIS NIGRITINCTUS HACHISUKA} White-throated Fantail Warbler

Hachisuka, Proc. Biol. Soc. Wash., vol. 54, p. 49, May 20, 1941. Delacour \& Jabouille, Ois. Indoch, vol. II, p. 84, 19.31. 
Two specimens.

Some members of Rhipidura are open country birds and familiar with human habitation while others are confined to high mountain forest. The present species has the habitat of the latter and is not common where found. Yen is the first and only ornithologist who collected this species within Chinese continent and secured and adult male in Loshiang, in Yaoshan range, in April 1929. Therefore, it must be an exceedingly rare bird. My two specimens brought back from Nanning show no individual variation.

Allied Races and their Range:

R. albicollis albicollis (Vieillot).

Himalayas from Murree to Eastern Assam, Burma, Shan States, Siam, Yunnan, Tonkin, North Annam, Hainan and according to Chasen the birds found in Kina Balu, Borneo belong to the typical race.

The Kwangsi birds are the first discovery of this genus from South China continent.

P. a. cinerescens Delacour.

Central and South Annam and Laos.

R. a. atrata Salvadori.

Malay Peninsula, Sumatra and Borneo except Kina Balu.

R. a. celsa Riley.

Mts. of Northern Siam.

\section{LANIUS SCHACH SCHACH Linnaeus}

Chinese Rufous-backed Shrike

La Touche, "Handb. Bds. E. China," I, p. 183, 1925.

Allied Races and their Range:

For the races of this shrike, Kuroda's "Birds of Java" vol. i, p. 146, 1933 should be consulted and furthermore the following two have been described since the publication of his book.

Lanius s. hainanus Birkhead.

Hainan.

Lanius s. lingulacus Hachisuka.

Yangtse Valley, China. 


\section{PERICROCOTUS SOLARIS MANDARINUS Stresemann.}

Fohkien Grey-throated Minivet

La Touche, "Handb. Bds. E. China," I, p. 196, 1926.

Allied Races and their Range:

$P$. solarius solarius Blyth.

Nepal to East Assam, both north and south of Brahmaputra,

Manipur, Burma, Chin and Kachin Hills to Tenasserim.

P. s. ripponi Baker.

Shan States.

P. s. griseigularis Gould.

Formosa.

$\dot{P}$. s. mandarinus Stresemann.

Fukien, Kwangtung, Kwangsi, N. E. and central Tonkin, Laos, and Annam.

The present race is not well defined and I have not recognized it in my book "Birds of the Philippine Islands," vol. ii, p. 365, 1935 but in 1940 Delacour accepts it in his Indo-Chinese handlist.

The Hainan specimen has not been examined but it should belong either to the present or to the Formosan race.

\section{LALAGE MELANOPTERA (Rippon) \\ Blacked-winged Cuckee-Shrike}

La Touche, "Handb. Bds. E. China," I, p. 202, 1926.

Distribution.-Burma from extreme north to south, the whole of Shan States, Yunnan, entire Indo-China and all China except Hainan, and extreme north of the continent.

The present bird has long been known as Lalage melaschista avensis (Blyth) and considered to be a race of the Indian birds but it is believed that both birds occur together in Yunnan. Robinson \& Chasen, "The Birds of the Malay Peninsula", vol. iv, p. $236,1939$.

DICRURUS MACROCERCUS CATHCECUS Swinhoe. Chinese Black Drongo

La Touche, "Handb. Bds. E. China," I, p. 206, 1926. 
Allied Races and their Range:

India, Ceylon, eastwards to entire China, including Formosa and Hainan, north to south Manchuria. In the Malay States it is only found in the peninsula Siam; one race is found in Java and Bali.

In this immense range the Black Drongo is subdivided about seven races. (cf Kuroda "Birds of Java, vol. i, p. 53, 1933).

\section{CHIBIA HOTTENTOTTA BREVIROSTRIS Cabanis \& Heine. Chinese Hair-Crested Drongo}

La Touche, "Hand. Bds. E. China," I, p. 209, 1926.

Allied Races and their Range:

C. hottentotta hottentotta Linnaeus.

Travancore, Malabar and Bombay Presidency; Central Provinces and Chota Nagpore; the Himalayas from Murree to Eastern Assam; Burma south to Tenasserim, Shan States, Northern Siam, Yunnan, and Indo-China.

C. h. brevirostris Cabanis \& Heine.

Entire China except Hainan and Formosa.

C. h. sumatranus (Ramsey).

Sumatra.

C. h. borneensis (Sharpe).

Borneo, Maratua Is., Bonao, Cagayan Sulu, Lapoc, off Siasi, Sibutu, Sulu, Tawi Tawi.

C. h. ter meuleni (Finsch).

Thouthand Islands, West Java.

C. h. jentinki Verderm.

Fast Java, Bali, Kangean Is.

C. h. sirensis (Oberholser) from Mata Siri and C. h. solombensis (Oberholser) from Solombo Besar in Java Sea are doubtfully separated from $C$. $h$. jentinki.

C. h. viridinitens (Salvadori),

Mentawi Is., W. Sumatra.

C. h. balicassius (Linnaeus). 
Lubang, Luzon, Marinduque, Mindoro, Polillo, Verde.

C. h. palawanensis (Tweeddale).

Balabac, Calamianes, Palawan.

C. h. cuyensis McGregor.

Cuyo.

C. h. worcesteri McGregor.

Semerara.

C. h. striata (Tweeddale).

Basilan, Bohol, Leyte, Mindanao, Nipa, Panaon, s' mar.

C. h. bimaënsis (Wallace).

Sumbawa, Flores, Pantar, Alor

C. h. sumber (Rensch).

Sumba.

C. h. vicinus (Rensch).

Lombok.

C. h. subsp.

Bali.

C. h. manumeten (Stresemann).

Ceram.

C. h. pectoralis (Wallace).

Sula Islands.

C. h. lomosticta (Sclater).

New Britain.

C. h. leucops Wallace.

Celebes.

\section{SEICERCUS BURKII VALENTINI (Hartert) \\ Bianchi's Flycatcher-Warbler}

La Touche, "Handbook Bds. E. China," I, p. 257, 1926.

One specimen.

Racial and even specific affinities are well confused and several names have been proposed but no satisfactory conclusion. has yet been reached. It is for this reason that I am not attempting to work throughly on this difficult group of Flycatcher-Warbler as materials at my disposal are far from complete. The trinominal 
appellation is tentative and we must wait until I am betier equip. ped to write.

The present record furnishes the first of this species from $\mathrm{K}$ wangsi, of course Yen did not record in his Yaoshan paper. The present species is said to be both resident and migratory and as my specimen bears no exact date $I$ am also at a loss to know its status in life.

Measurements. Wing 60; tail 43; tatsus 18 ; bill 10 .

Allied Races and their Range:

S. burkii burkii Burton.

Himalayas except northwest and hills south and east of the Brahmaputra.

S. b. whistleri Ticehurst.

N. W. Himalaya.

S. b. tephrocephalus (Anderson).

Hills of Burma from Chin Hills to Shan States, Laos, North Annam, and Cambodia.

S. b. affinis (Horsfield and Moore).

Sikkim to North Assam, north and south of the Brahmaputra,

Chin and Kachin Hills, South Annam, and High Laos.

S. b. distinctus (La Touche).

N. E. Tonkin, North Annam, and High Laos.

S. b. intermedius (La Touche).

High Tonkin, North Annam, Laos, Yunnan, Kwangtung, N. W. Fukien and Kwangsi.

S. b. valentini (Hartert).

Kwangtung, Fukien, Hupeh, Kansu, and Shensi.

S. b. cognitus (La Touche).

N. W. and central Fukien.

Bangs published a small paper on Seicercus of the burkii form circle Proc. New Eng. uool. Club, xi, pp. 1-5, May 8, 1929, but was not well accepted.

\section{ORIOLUS CHINENSIS DIFIUSUS Sharpe Black-naped Oriole}

La Touche, "Hankb. Bds. E. China," I. p. 277, 1926. 


\section{ORIOLUS TRAILLII MELLIANUS Stresemann South China Maroon Oriole}

Stresemann, “Orn. Monatsb.," XXX, pt. 3, p. 64, 1922.

Meinertzhagen, Ibis, 1923, p. 95.

La Touche, "Handb. Bds. E. China," I, p. 279, 1926.

Delacour, Ibis, 1929, p. 424.

Yen, Bull. Dept. Biol. Canton, Bds. from Yaoshan, p. 19, 1930.

Delacour \& Jabouille, Ois. Indoch., IV, p. 268, 1931.

Delacour \& Jabouille, L'Oiseau, Liste Ois. l'Indoch., Nos. 1-2, p. 217, 1940.

Two specimens.

This rare oriole was first collected during the expedition of the Sun Yat-sen University in Canton, on the upper waters of the West River above Canton, hitherto hardly known ornithologically. The specimen was but one female and it was sent to Dr. Stresemann together with other things to be identified and was named as a race of traillii. The subspecific name was given in honour of Herr Mell, its collector. The chief distinguishing marks are that the feathers of the back are not blackish smoke-brown as in O.t. traillii but resembles more the back of $O$. $t$. ardens or nigellicauda. The under tail-coverts is a delicate rose colour, much paler than in the other races. Wing of type, 141; exposed culmen, $27 \mathrm{~mm}$. Although Colonel Meinertzhagen in his revicw of the orioles states this bird, he did not examine the specimen. La Touche also was unacquainted with this oriole.

Nine years after the first discovery in Kwangtung Monsieur Delacour rediscovered it from Cambodia by obtaining only one female. Delacour (1929) writes as:- "At Bokor on 12th December, 1927, we collected one female exactly similar to that obtained by Mell near Canton, with a wholly grey back. 'The native hunter who shot it said that there was a red oriole in its company which escaped. In spite of our careful search we were unable to see any more of these strange birds. It is remarkable to have found in the south of Cambodia in the winter, the bird only once before met with in May in southern China, which might indicate migra- 
tory habit. No other red orioles was seen in Cambodia, which rather removes the chance of its being a sport."

The Sun-Yatsen University undertook another zoological expedition and this time they selected the now much faned Yaoshan in Kwangsi Province, staying exactly two years (May 1928-May 1930). Prof. Yen reports that they collected a good number of this oriole, both adults and young of the both sexes, found at Loshiang from April to August. On my visit to this University in Canton in May I found that all the staff had been evacuated and not a single of the 4,000 Yaoshan specimens had been found. A male specimen was obtained for the first time in the southeast Siam. This record is after Delacour's 1931 article but I did not take the trouble to find out the original statement.

All the above record is sufficient to know that this oriole breeds in the mountains of southern China and migrates south in winter to Siam and Cambodia.

I have before me two specimens, presumably females, brought back from Nanning and on my careful comparison with Formosa and Hainan skins the characteristics given by Stresemann are clearly recognizable.

Allied Races and their Range:

O. trailli trailli (Vigors).

Throughout the Himalayas from the Sutlej Valley to Eastern Assam, Manipur, the hilly tracts of Burma, Tenasserim, Shan States, Siam, Laos, Tonkin and North Annam.

o. $t$. robinsoni Delacour.

South Annam and lower Laos.

O. t. nigellicauda (Swinhoe).

Tonkin, upper Laos and north Annam, and Hainan.

o. t. mellianus Stresemann.

Kwangtung and Kwangsi, Migrates to Cambodia and Siam. Like the describer of this bird, La Touche considers the present Oriole as a race of trailli, however, Delacour considered it to be a distinct species. It breeds in Yaoshan, in Kwangsi Province and taken during winter as migrating in Siam and Cambodia.

$O$. $t$. ardens (Swinhoe). 
Formosa.

ACRIDOTHERES CRISTATELLUS CRISTATELLUS

(Linnaeus)

Chinese Crested Mynah

La Touche, "Handb. Bds. E. China," I, p. 291, 1926.

Allied Races and their Range:

A. cristatellus cristatellus (L.)

South China from South Yunnan to the Yangtse Valley inclusive. Reaching in Shensi to the Hanchong-fu Valley.

In Indo-China it is found in Tonkin, Annam, and Cochin-China. Introduced into Manila.

A. c. brevipennis Hartert.

Hainan.

According to Delacour, 1940, the Indo-chinese birds are the typical race and brevipennis is not recognized.

A. c. formosanus (Hartert).

Formosa.

\section{LONCHURA PUNCTULATA TOPELA (Swinhoe)}

Chinese Spotted Munia

La Touche, "Handb. Bds. E. China," I, p. 294, 1927.

Allied Races and their Range:

The species is distributed from India and Ceylon in the west and eastwards to the tropical China including Formosa and Hainan. In the south it is found in the Malayan Islands, Philippines, Celebes and the Moluccas.

For the subspecies, see Kuroda's "Birds of Java," vol. i, p. 72, 1933. The locality Indo-China must be added to the distribution of $M$. p. topela.

\section{GALLICREX CINEREA (Gmelin) \\ Water Cook}

La Touche, "Handib. Bds. E. China," II, p. 286, 1932. 
PASSER MONTANUS SATURATUS Stejneger.

Chinese Tree-Sparrow

La Touche, "Handb. Bds. E. China," I, p. 328, 1927.

\section{PASSER RUTILANS RUTILANS Temminck}

La Touche, "Handb. Bds. E. China," I, p. 330, 1927.

\section{EMBERIAN TRISTRAMI Swinhoe \\ Tristram's Bunting}

La Touche, "Handb. Bds. E. China," I, p. 352, 1927.

A female specimen in the Nanning Museum.

\section{EMBERIZA AUREOLA Pallas Yellow-breasted Bunting.}

La Touche, "Handb. Bds. E. China," I, p. 375, 1927.

\section{MELOPHUS MELANICTERUS (Gmelin) \\ Grested Bunting}

La Touche, "Handb. Bds. E. China," I, p. 378, 1927.

Delacour in, 1940, uses lathami of Gray which is the next oldest name to melanicterus but $I$ have so far been unable to know why the well known name melanicterus is no longer able to be used, so during the mean time I have followed the earlier writers, such as S. Baker and La Touche.

Distribution.-No local names has yet suggested and it ranges from lower Himaiayas from Kashmir to East Assam, the hill country of Western India and Rajputana to Lohardaga and Bihar, Manipur, Chin and Kachin Hills in Burma, Tenasserim, Tonkin, Laos and N. Annam. In Indo-China and in South China they are found in Chekiang, Fukien, Kwangtung, Yunnan, Szechwan, Moupin (on W. Szechwan Tibetan border). 
HIRUNDO RUSTICA GUTTURALIS Scopoli. ツパヌ.

La Touche, "Handb. Bds. E. China," I, p. 392, 1927.

HIRUNDO DAURICA DAURICA Linnaeus.

Daurian Striated Swallow

La Touche, "Handb. Bds. E. China," I, p. 395, 1927.

\section{MOTACILLA ALBA BAICALENSIS Swinhoe}

La Touche, "Handb. Bds. E. China," I, p. 399, 1930.

\section{MOTACILLA CINEREA CASPICA (Gmelin) \\ Eastern Grey Wagtail}

La Touche, "Handb. Bds. E. China," I, p. 408, 1930.

\section{EMBERIZA PUSILLA Pallas \\ Little Bunting}

La Touche, "Handb. Bds. E. China," I, p. 348, 1927.

The specimens examined at the Nanning Museum came from P'ing nan (平南).

\section{ANTHUS RICHARDI RICHARDI Vieillot}

Richard's Pipit

La Touche, "Handb. Bds. E. China," I, p. 432, 1930.

The specimens examined at the Nanning Museum came from Ho ch“i (河池).

\section{ÆTHOPYGA CHRISTIN E LA'TOUCHII Slater \\ La Touche's Sunbird}

La Touche, "Handb. Bds. E. China," I, p. 461, 1930. 
Allied Races and their Range:

A. c. christince Swinhoe.

Hainan.

E. c. latouchii H. H. Slater.

Tonkin, Annam, Cochin-China, Fukien, Kwangtung, Kwangsi, ? Szechwan.

Hainan has one representative of each Cynnyris and Ethopyga but Family Nectariniida is unknown from Formosa.

\section{ÆTHOPYGA SATURATA SANGUINIPECTA Walden Walden's Yellow-backed Sunbird}

Yen and Chong, L'Oiseaux, vol. III, No. 4, p. 552, 1927. Tung-Lan and Si-Ling, Kwangsi.

Two already known species of sunbirds from China, christina and siparaja are found as far east as Kwangtung and Fukien and this beautiful species is confined to S.W. China which is the range of Yaoshan. La Touche already suggested the occurrence of the present Sunbird within his territory in his book, Vol. I, p. 464, stating that Yunnanese Sunbirds may stray to southernmost Kwangtung. Yen and Chong recorded the first specimen from $\mathrm{K}$ wangsi, which came from Tung-Lan and Si-Ling. Therefore, my specimen forms the second record from that province and La Touche's hypothesis is now gradually being proved.

The present species has two well defined races, the western is a dark bellied and the eastern is light coloured which is an olive bellied bird.

Athopyga saturata saturata (Hodgson)

Garhwal, Nepal, Sikkim, Assam, Cachar, Manipur, Chin Hills and Yunnan.

Ethopyga saturata sanguinipecta Walden

South Shan States, Karen Hill, South to Muleyit in Tenasserim, Yunnan, Indo-China, and Kwangsi.

Stuart Baker (1926) records both races from Yunnan but Rothschild (1926) considers all Yunnanese birds to be sanguinipecta. 
Robinson and Kloss described their johnsi from South Annam as a race of sanguinipectus but Delacour considers it as a distinct species.

\section{DICAEUM SANGUINOLENTUM IGNIPECTUM (Hodgson)}

Fire-breasted Flower-Pecker

La Touche, "Handb. Bds. E. China," I, p. 467, 1930.

Allied Races and their Range:

D. sanguinolentum ignipectum (Hodgson).

Himalayas from the Sutlej Valley to Eastern Assam, Manipur and South Assam; the mountains of Burma to Tenasserim, Siam, Laos, Tonkin, north and south Annam, Fukien, Kwangtung, Yunnan, Szechwan, also Malay States.

In this immence range there seems to be no variation except in N. W. Himalaya which is paler below and less rich buff in both male and females and Mr. S. Baker thinks ("Fauna Brit. India Bds." vol. iii, p. 428,1926$)$ this may be proved eventually as a geographical race.

The species are divided into several races in the islands.

D. s. formosum O. Grant.

Formosa.

D. s. sanguinolentum Temminck.

West Java.

D. s. ablutum Robinson \& Kloss.

East Java, Bali and Lombok.

D. s. beccarii Robinson \& Kloss.

Sumatra.

D. s. monticolum Sharpe.

Borneo.

D. s. rhodopygiale Rensch.

Flores.

D. (? s.) hanieli Hellmayr.

Timor.

Deignan described the following bird from Northern Siam believing the birds from Malay States hitherto known as ignipectum, 
probably apertain to this new race.

D. ignipectus dolichorhyncum Deignan (1938).

Khao Nom Plu, 3,000 ft. Trang Province, Peninsular Siam.

\section{PITTA SOROR TONKINENSIS Delacour. \\ Tonkinese Blue-naped Pitta}

Delacour \& Jabouille, Ois. Indoch., Vol. III, p. 21, 1931.

Two specimens.

Yen collected more than ten specimens at Loshiang, Yaoshan between April to July and November to February, and the present record forms the second occurrence of this species from Kwangsi; moreover from the Chinese continent.

Allied Species and their Range:

$P$. soror soror Wardlaw Ramsey.

Cochin China, Cambodia, Southern half of Annam.

P. s. petersi Delacour.

Central Laos, North Annam.

$P$. s. tonkinensis Delacour.

Tonkin, Kwangsi.

P. s. douglasi Ogilvie-Grant.

Interior of Hainan.

Pitta soror is closely related to $P$. nipalensis, Blue-naped Pitta, which has the following races.

P. nipalensis nipalensis (Hodgson).

The lower Himalayas from East Nepal to the extreme east and south of Assam; Manipur, Hill Tippera and Chittagong Hill Tracts in eastern Bengal; Lushai and Chin Hills to north Arakan. $P . n$. hendeei Bangs \& Van Tyne.

Tonkin, High Laos, extreme north Annam.

P. n. schneideri Hartert.

Sumatra.

\section{DRYOBATES MAJOR STRESEMANNI Rensch} Stresemann's Pied Woodpecker

Dryobates major stresemanni Rensch, Zool. Erg. W. Stotz. 
Exp. in Abh. and Ber. Mus. Dresd., Vol. XVI, No. 2, pt. iii, p. 38, 1924, Tsalila.

Rothschild, Avif. Yunnan etc., Nov. Zool., XXXIII, p. 240, 1926.

La Touche, "Handb. Bds. E. China," II, p. 18, 1931.

Prof. Yen did not discover the Pied Woodpecker from Yaoshan but he shot one in Tsienkong. The present specimen obtained at T'ien pao (天保), though I did not bring over to Japan for comparison, may safely be named as stresemanni. Like Hartert, Rensch and Rothschild D. major and D. cabanisi are considered as conspecific. cf. Rothschild 1926.

\section{SASIA OCHRACEA KINNEARI Stresemann \\ Chinese Rufous Piculet}

Journ. für Orn., 1929, LXXVII, p. 335. Yaoshan.

La Touche, "Hand. Bds. E. China," II, p. 29, 1931.

Two specimens.

This characteristic genus to the Oriental Region which is widely distributed throughtout its territory includes but two allied species ochracea and abnormis.

Allied Races and their Range:

S. ochracea ochracea Hodgson.

Garhwal, Nepal, Sikkim, east to Dibrugarhin, Assam, north of the Brahmaputra, Kachin Hills in Burma.

S. o. querulivox S. Baker.

Assam, south of the Brahmaputra, Maripur, Hill Tippera and Chittagong in eastern Bengal, Chin Hills in N. W. Burma, Tonkin, Laos and N. Annam.

S. o. reichenowi Hesse.,

Burma from the lower Chindwin, Tounghoo, South Shan States to Mergui and Ye in Tenasserim, Peninsular Siam, Cochin China, central and S. Annam, and lower Laos.

S. o. kinneari Stresemann.

Yunnan (Hokow by La Touche; Lankay by Kuroda), Kwangsi (Yaoshan by Yen). 


\section{CYANOPS FABAR SINI Stresemann \\ Chinese Barbet}

Journ. für Orn., 1929, LXXVII, p. 336. Yaoshan.

Two Specimens.

This barbet is very close to the Hainan barbet but the green of the back is slightly darker, bill slightly short and blunt. The amount of red nuchal patch varies a good deal but the blue feathers on the nape is more distinct. Some Hainan specimens have nearly no blue on the nape. The barbets appears to be very common in Hainan and large member of specimens have been collected but it appears scarce in Yaoshan.

JYNX TORQUILLA JAPONICA Bonaparte.

Japanese Wryneck $\boldsymbol{Y}$ スヒ

La Touche, "Handb. Bds. E. China," II, p. 30, 1931.

The specimens examined at Nanning Museum came from $\mathrm{P}^{\text {ing }}$ nan 平南) and Yaoshan (萄山).

\section{HIEROCOCCYX SPARVEROIDES (Vigors) \\ Large Hawk-Cuckoo オホジフイチ}

La Touche, "Hand. Bds. E. China," II, p. 46, 1931.

The specimens examined at Nanning Museum came from Nanning (南寧).

\section{SURNICULUS LUGUBRIS DICRUROIDES (Hodgson) Indian Drongo-Cuckoo}

La Touche, "Handb. Bds. E. China," II, p. 52, 1931.

Allied Races and their Range:

For the allied races and their distribution it is advised to consult my book "Birds of the Philippine Islands" vol. ii, p. 196-198, 1934 , but of course, Kwangsi must be added to dicruroides.

Chasen's (Handlist of Malaysian Birds, p. 122, 1935) has a 
little different distribution compared to my work and includes a doubtful barussarum of Oberholser from Batu Is., W. Sumatra.

The specimens examined at Nanning Museum came from P'ing nan (平南) and Yaoshan (厒山).

\section{CENTROPUS BENGALENSIS BENGALENSIS (Gmelin) \\ Lesser Crow-Pheasant}

La Touche, "Handb. Bds. E. China," II, p. 59, 19.31.

\section{ALCEDO ATTHIS BENGALENSIS Gmelin \\ Common Indian Kingfisher}

La Touche, "Banb. Bds. E. China," II, p. 75, 1931.

\section{HALCYON PILEATUS PILEATUS (Boddaert) \\ Black-capped Kingfisher}

La Touche, "Handb. Bds. E. China," II, p. 79, 1931.

Commonly seen in the neighbourhood of Nanning. I saw a pair courting in the rice field and bare hillside towards the end of May.

\section{OTUS BAKKAMOENA GLABRIPES (Swinhoe)}

Bare-footed Scops-Owl

Wilder, Gee \& Moffett, Chinese Birds, p. 122, 1926-27.

Baker, S., "Faun. Brit. India," IV, p. 422, 1927.

La Touche, "Handb. Bds. E. China," vol. II, p. 118, 1932.

Hachisuka, Kuroda, Taka-Tsukasa, Uchida, Yamashina, "Handlist Jap. Bds." p. 88, 19.32.

- Hachisuka, "Bds. Philip. Is." vol. II, p. 53, 1934.

Chasen, "Handlist Malay. Bds." p. 86, 1935.

Kuroda, "Bds. Java," vol. II, p. 484, 1936.

One specimen.

From South China Swinhoe named three Scops-Owls of bakka- 
moena group. In 1870 he named umbratilis from Hainan and glabripes from South China and Formosa. Both nomes have been well accepted and used by the South Chinese authors. Recently Delacour in his Ois. Indochine, p. 125, 1940 suggested that glabripes be united with lettia of northeastern India. However the specimens before me clearly show the difference between the two forms, and like the former authors I keep the two separate.

Swinhoe in 1874 again separated Canton and S. Fukien bird and called it erythrocampe. This name was somehow not noticed by La. Touche in his book but he suggested the probable second race of bakkamoena from Eastern China. La Touche did not name his bird (Vol. II, p. 121) but this probable new race is distributed to Moupin (borderes of western Szechuen), Hupeh, Chinkiang, Shanghai and Ningpo. In the checklist of the Chinese birds the three American writers also did not refer to erythrocampe. Therefore this name has been quietly turned into a synomym of glabripes. According to Swinhoe glabripes is found in South China and Formosa, and my Nanning specimen is a typical glabripes which shows no affinity to the further western races.

The race lettia has fairly strong rufous tinge throughout the body and it becomes sandy and darker grey as it comes further east. The same tendency is traceable between series of South Chinese and Formosan skins. I have seen several Formosan skins but few from South China, so I refrain from naming the Formosan bird at present.

\section{GLAUCIDIUM CASTANOPTERUM WHITELYI (Blyth) Whitelys' Barred Owlet}

La Touche, "Handb. Bds. E. China," II; p. 126, 1932.

For the allied forms see Kuroda's "Birds of Java," rol. ii. p. 491, 1936.

FALCO PEREGRINUS PEREGRINATOR Sundevall Shahin Falcon ムネアカーヤブサ

.La Touche, "Handb. Bds. E. China," II, p. 137, 1932. 


\section{CIRCUS MELANOLEUCUS (Forster). \\ Pied Harrier}

La Touche, "Handb. Bds. E. China," II, p. 178, 1932.

Adult and juvenile specimens were examined.

\section{ACCIPITER TRIVIRGATUS RUFITINCTUS (Horsfield) \\ Large Crested Goshawk}

Baker, "Fauna Brit. Ind. Bds.," V, p. 155, 1928.

Hachisuka, "Bds. Philip. Is.," vol. II, p. 6, 1934

Yen obtained one specimen in May at Loshinng, in Yaoshan and the present forms the second record.

The present Goshawk has never been found in S.E. China or in northern Philippine Islands but it is recorded from Formosa and east, central and southern Philippines.

Contrary to Baker, Peters, Japanese Handlist (19.32) and myself, Kuroda (Bds. Java, 1936) employs indicus and not rufitintus for this bird. The author of rufitinctus is Horsfield in McClleland's MS. and not Mcclleland himself as stated by Baker and the Japanese Handlist.

The specimens examined at Nanning Museum came from Nanning (南寧).

\section{AVICEDA LEUPHOTES (Dumont) Black Grested Baza}

This beautiful falcon is still a rare bird in China, Mell obtained a female in a mountain wood near Lungtou Shan in Kwangtung Province in October and Sin secured a series of seven at Yaoshan. My Nanning bird, probably obtained also in Yaoshan or its neighbouring high hills, constitute the third record from China. It is. also recorded from Tonkin. My specimen is an adult with dark chestnut band across the lower breast.

Mr. Sclater's burmana is recognized by Baker but not by Delacour or Chasen (1935). 
ENOPOPELIA TRANQUEBARICA HUMILIS (Temminck)

Burmese Red Turtle-Dove ベニバト

La Touche, "Handb. Bds. E. China," II, p. 216, 1932.

\section{PHASIANUS COLCHICUS subsp.?}

Chinese Ring-necked Pheasant

Rothschild, Nov. Zool., On the Avif, Yunnan etc., XXXIII, p. 207, 1926.

Delacour \& Jabouille, Ois. Indoch., vol. II, p. 257, 1931.

La Touche, "Handb. Bds. E. China," I, p. 228, 1932.

Two female specimens.

Having examined only two females and never seen a male specimen, I am not qualified to discuss the affinity of the Ring-necked Pheasant here. Yen only obtained one Yaoshan specimen. The names proposed for the birds found near Kwangsi are as follows:

Phasianus c. elegans Elliot from Yu-iing Mts., W. Szetschuan and Phasianus c. rothschildi La Touche from Mengtsz, Yunnan are known but the latter name has been turned into a synonym of the former by Lord Rothschild but later recognized by Delacour and applied to the birds found in the N. W. Tonkin and the frontier between Tonkin and Laos. In the entire Indo-China, Tonkin is the only place where the true pheasant is found and as many as four races are recognized. One is rothschildi as already mentioned and the second is takatsukasce of Delacour from Langson, Eastern Tonkin, and the third is tonkinensis Delacour and Jabouille from the high hills of Fansipan in N. W. Tonkin and lastly the typical torquatus of S.E. China is recorded from Nyganson, N.W. Tonkin. I have full reason to believe that the present range of the typical torquatus is too extensive, as specimens in my collection from Hong Kong and Shanghai are certainly different. We require more material from North, East, and Central China to discuss the subspecific affinity of the so-called torquatus group. 
GENNAEUS NYCTHEMERUS NYCTHEMERUS (Linnaeus) Common Silver Pheasant

La Touche, "Handb. Bds. E. China," II, p. 245, 1932.

Two female specimens, having very dark underparts, examined" at Nanning Museum came from P'ing nan (平南).

Mr. Fok has published in Hong Kong Naturalist, vol. viii, No. I, April 1927, an article entitled "Birds of Kwangtung, Kwangsi and Fukien", forming a list of birds obtained from those provinces which are preserved at the Sun Yat-sen University, Canton. In this list Gennaeus whitcheadi is included to occur from Yaoshan, Kwangsi. Yaoshan is a very interesting mountain of that province where several of Yunnan and Hainan species have been obtained. Therefore, the record of, so far believed to be, an endemic Silver Pheasant from Hainan mountain certainly struck my special attention.

During my visit to Nanning, the capital of Kwangsi Province, I wa sable to examine two stuffed specimens of female Silver Pheasant, and its unusually blackish belly struck my attention. These females are not so broadly marked as the females of whiteheadi but nearest to the typical birds.

On my visit to Nanking Museum, October 1941, I was able to study four specimens of Silver Pheasant, no doubt the duplicate specimens of which Mr. Yen collected at Yaoshan. These were all males and I am now convinced that they belong to the typical race.

The typical Silver Pheasant is therefore, known from Fukien, N. Kwangtung (La Touche), N. E. Tonkin (Delacour) and Yaoshan, Kwangsi.

\section{ARBOROPHILA GINGICA (Gmelin)}

\section{Rickett's. Hill Partridge}

La Touche, "Handb. Bds. E. China," II, p. 256, 1932. Peters, "Checkl. Bds. World, "vol. III. p. 100, 1934.

Two specimens. 
This rare Partridge requires some comment. Among many valuable specimens preserved in the Leyden Museum, there are two Partridges which I examined some years ago; one is a unique specimen of a large Partridge from New Guinea and the second is the type specimen of Arboricola gingica by Blyth.

The Marquis of Tweeddale believed and expressed in Trans. Zool. Soc., ix, p. 223, 1875 that the probable locality of this bird is Luzon and not Coromandel coast in India, although he does not think that Marten's Arboricola sp. J. f. O., 1866, p. 25, No. 142 is the same species.

After those authors we are since mislead to believe that Euzon is a home of a certain Arborophila and Prince Taka-Tsukasa repeats the same mistake in his "Birds of Nippon." Vol, I, Part 4, p. 188, 1934.

Ogilvie-Grant published a useful review on genera Bambusicola and Arboricola and coloured drawing of the Leyden bird was reproduced in Ibis 1892, vol. iv, pl. ix. This article soon required anotation as during the following year a new species $A$. ardens from Hainan mountain has been discovered and figured by Styan in Ibis 1893, vol. v, pl. xii.

We know now for certain that the home of $A$. gingica is south China and several specimens have been collected although it is still a localized rare hill bird. The known localities are Central Fukien, North Kwangtung Yaoshan in Kwangsi.

During my last journey to South China, I was able to secure two specimens from Yaoshan and was fortunate enough to examine a Kwangtung specimen at the Lingnan University.

This Kwangtung specimen has much paler upper part, the crown light chestnut and the forehead is white which is as wide as $10 \mathrm{~mm}$., and it extends above the eye forming a very wide and short superciliary stripe. The slate blue colour of the breast is much paler but the flank has the same chestnut marking as the Yaoshan specimen.

We know that $A$. ricketti which is a synonym to $A$. gingica has a very white forehead, therefore Lingnan University specimen must have the same plumage as the type of ricketti. 
Yaoshan bird differs furthermore by having wider white collar on the throat. Lingnan University specimen has the following measurements. Wing 143; tail 72; bill 18; and tarsus $44 \mathrm{~mm}$.

My two Yaoshan specimens differ from the Leyden specimen chiefly on the head. My specimens have distinct white front and white superciliary stripe behind the eye which is mixed with black stripes, the throat being rich chestnut.

The Leyden specimen has no white on the head, and throat being greyish and rufous is only showing some distance below, that is to say, just above the black collar. It appears to me that the Leyden bird is not fully grown and bright plumage on the head is not yet developed.

During my two expeditions to the Philippine Islands I was much interested in the Partridges from Luzon but was unable to get any information except the introduced Francolinus.

During his collecting journey to north Luzon, Whitehead particularly looked for the peacock pheasant and he was satisfied toward the end that such pheasant does not exist in Luzon although endemic species is found in a much smaller island of Palawan which is nearer to Borneo. If Arboricola ever exists in Luzon, it is difficult to believe that it has escaped Whitehead's attention. It is however Marten's specimen is still a mystery and we have to look for a bird which the plumage matches his description which is as follows:-Head green-black; breast wine-red, streaked with black; side pale red, spotted with black.

The Hainan Hill Partridge is one of the most striking of the Hainan avifuna and to my knowledge only a few specimens are kept in London and New York. On looking carefully, the illustration in Ibis the back and wing are much the same as gingica and both have flesh coloured legs and black bill, although it is quite distinct that ardens appears to be nearest to gingica.

The subspecific names are given to the specimens obtained in Fukien, Kwangtung and Kwangsi and Peters is probably right in uniting them all, as my two specimens from Yaoshan proves to have quite an individual variation. 
BAMBUSICOLA THORACICA THORACICA (Temminck) Chinese Bamboo Partridge

La Touche, "Handb. Bds. E. China," II, p. 251, 1932.

One specimen.

EXCALFACTORIA CHINENSIS CHINENSIS (Linnaeus)

Blue-breasted Quail ヒメウッ゙ラ

La Touche, "Handb. Bds. E. China," II, p. 252, 1932.

The specimens examined at Nanning Museum came from P'ing nan (平南).

COTURNIX COTURNIX JAPONICA Temminck \& Schlegel. Japanese Grey Quail •ウッ゙ラ

La Touche, "Handb. Bds. E. China," II, p. 253, 1932.

FRANCOLINUS PINTADEANUS PIN'TADEANUS (Scopoli) Chinese Francolin

La Touche, "Handb. Bds. E. China," II, p. 260, 1932.

Two specimens.

TURNIX SYLVATICA DUSSUMIERI (Temminck)

Little Button Quail

La Touche, "Handb. Bds. E. China," II, p. 268, 1932.

One specimen.

TURNIX MACULATUS MACULATUS Vieillot.

Burmese Buttor-Quail

La Touche, "Handb. Bds. E. China," II, p. 269, 1932.

One specimen collected at -Longcheo (龍州) which Yen did not 
find in Yaoshan. The well known name blanfordi is replaced by maculatus.

\section{HYPO'T ENIDIA STRIATA GULARIS (Horsfield)} Indian Banded Rail

La Touche, "Handb. Bds. E. China," II, p. 275, 1932.

PORZANA FUSCA ERYTHROTHORAX (Remminck \& Schlegel). Chinese Ruddy Crake

La Touche, "Handb. Bds. E. China," II, p. 278, 1932.

AMAURORNIS PHCENICURA CHINENSIS (Boddaert).

Chinese White-breasted Water-Hen

La Touche, "Handb. Bds. E. China," II, p. 283, 1932.

\section{GALLINULA CHLOROPUS INDICUS Blyth} Indian Moorhen

La Touche, "Handb. Bds. E. China," II, p. 284, 1932.

EROLIA MINUTILLA SUBMINUTA (Middendorf)

Long-toed Stint

LLa Touche,. "Handb. Bds. E. China," II, p. 385, 1933.

\section{CAPELLA GALLINAGO GALLINAGO (Linnaeus) Eastern Fantail Snipe}

La Touche, "Handb. Bds. F. China," II, p. 404, 1934.

\section{ARDEOLA BACCHUS (Bonaparte) \\ Chinese Pond-Heron}

La Touche, "Handb. Bds. E. China," II, p. 454, 1934. 


\section{BUTORIDES STRIATUS JAVANICUS (Horsfield) \\ Indian Little Green Heron}

La Touche, "Handb. Bds. E. China," II, p. 456, 1934.

NYCTICORAX NYCTICORAX NYCTICORAX (Linnaeus).

Night Heron

La Touche, "Handb. Bds. E. China," II, p. 457, 1934.

Common in town of Nanning and many were seen roosting in colonies on fairly low trees in the garden.

DUPETOR FLAVICOLLIS FLAVICOLLIS (Latham)

Yellow-necked Bittern

La Touche, "Handb. Bds. E. China," II, p. 467, 1934. 